\title{
A Literature Review on Using Women as A Sex Appeal in Advertisement
}

Aaila Jamila Binti Mohd Yusop, Tan Seng Teck, Wong Chee Hoo, Alex Hou Hong Ng, Toong Hai Sam

To Link this Article: http://dx.doi.org/10.6007/IJARBSS/v11-i2/8801

DOI:10.6007/IJARBSS/v11-i2/8801

Received: 01 January 2021, Revised: 29 January 2021, Accepted: 09 February 2021

Published Online: 23 February 2021

In-Text Citation: (Yusop et al., 2021)

To Cite this Article: Yusop, A. J. B. M., Teck, T. S., Hoo, W. C., Ng, A. H. H., \& Sam, T. H. (2021). A Literature Review on Using Women as A Sex Appeal in Advertisement. International Journal of Academic Research in Business and Social Sciences, 11(2), 320-329.

\section{Copyright: (c) 2021 The Author(s)}

Published by Human Resource Management Academic Research Society (www.hrmars.com)

This article is published under the Creative Commons Attribution (CC BY 4.0) license. Anyone may reproduce, distribute, translate and create derivative works of this article (for both commercial and non-commercial purposes), subject to full attribution to the original publication and authors. The full terms of this license may be seen at: http://creativecommons.org/licences/by/4.0/legalcode

\section{Vol. 11, No. 2, 2021, Pg. 320 - 329}

Full Terms \& Conditions of access and use can be found at http://hrmars.com/index.php/pages/detail/publication-ethics 


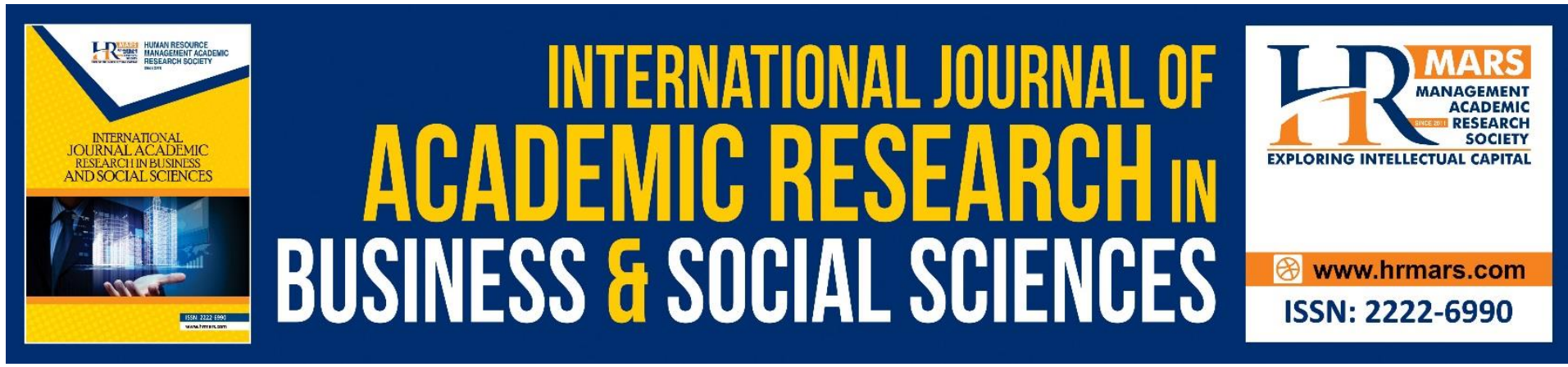

\title{
A Literature Review on Using Women as A Sex Appeal in Advertisement
}

\author{
Aaila Jamila Binti Mohd Yusop, Tan Seng Teck, Wong Chee \\ Hoo, Alex Hou Hong Ng, Toong Hai Sam
}

Inti International University Nilai, Persiaran Perdana BBN, Putra Nilai, 71800, Nilai, Negeri

Sembilan

Email: i18014864@student.newinti.edu.my

\begin{abstract}
Advertisement are one of the most important element of a business. It is important for a business to pick the most reliable platform to advertise. Moreover, it is equally crucial to pick the right advertising methods to maximize the number of viewers and consumers whom will be attracted to the products or services offered. Wrong decision made on the delivery of the advertisement might not be able to attract the right viewers and potential targeted customers.

Among the strongest subject used in advertisements are women. Women were made as the main attention and main focal point in selling products or services. Reasons stated that women were mostly appear in advertisement due to women unique characters and persona. Furthermore, women were usually seen as more pleasurable than men. Moreover, women ability to express emotions has become one of the score points for great attraction for an advertisement.
\end{abstract}

Due to the attractions possess by women, there are unlimited number of organization exploiting women as their main subject in an advertisement. In certain situation almost objectifying women in the advertisement. Women models were told to post in provocative manner while wearing provocative cloths to enhance viewer's acceptance specifically male. Women in advertisement were not only use to promote items for women brands or cloth line. Due to men less likely to be attracted with another male, women were also use in promoting men's brand. This long history of negative believe allows continuation of using women as an attraction in an advertisement.

Excessive use of women in advertisement in provocative manner permitted women to be seen as a mere object. It may bring down women's dignity and it causes less respect towards women in a society. Fortunately, even though marketers or organization are still using women in their advertisements the trend are no longer having great acceptance. Due to nongovernment movement campaign society learnt the value of women and refuse to see women as an object. Nowadays, viewers prefer to have better and more relatable content in an advertisements to accept the products and services offered by an organization.

Keywords: Ethical Advertising, Unethical Advertising, Sex appeal advertisement. 


\section{Introduction}

Advertising is an important part of marketing. Advertising helps companies to announce their new product to the market. Advertising in general is a good marketing strategies in improving acknowledgement of products, services and establishments (Huq, Nekmahmud and Aktar, 2016). Thus, advertising a product becomes one of the ways to ensure revenue coming in for a company. Only with proper awareness than a brand will be known and accepted in the business. This awareness is gained through advertising to ensure that it is planted in the mind of the viewer (McDonald and Sharp, 2003). As the world evolves, advertising is not limited to television and newspaper only. It evolved and all media nowadays are all seen as a way to promote and advertise products. People nowadays are getting more occupied than before thus the tendency to focus on one media is lesser (Harrington, Kizer, Khanfar and Wright, 2010). Besides, with the advancement of technology more people are not only relying on one media to gather information but also considering information from other sources. The sources will be social media such as instagram, tik tok, facebook and etc. Thus, it makes information reach the users faster than ever.

Ethical advertising can be define as an advertisement with certain criteria. The criteria included for an ethical advertisement are advertisements that did not have wrong claim, the purpose of the advertisement are clear and not ambiguous and the advertisement did not play with viewers or potential customer's belief system (Munjal, 2016). On the other hand, advertising may become unethical if it contain misguided information, leading to ambiguous information, extravagant claims on products that may give bad influence to consumers and explicit contents that may lead to immoral situation (Huq, et. al, 2016). Adding to the previous statement, giving the wrong impression, unnecessary hype to a product, stereotyping, racial issues and promoting controversial products are among the most common methods used in promoting products. Due to strong and hectic competition among companies in releasing products and services, the advertising marketing nowadays is considering less positive impact to the users and potential users. More and more unethical ways of promoting products are done to ensure the products and services are visible to users without considering the after effect of the advertisement. Advertising nowadays are looking forward to on how it can benefit in terms on profit more than sharing reliable information to consumers and the ways marketers are influencing customers are through exaggeration of information and using appeals that may triggered consumers attention (Haque, Abdullah and Shafiq, 2016). One of the way of unethical advertising include woman stereotyping (Munjal, 2016). Women stereotyping has led marketers excitedly using sex appeal advertisement in order to ensure manufacturer's products and services will grab consumer's attention even though the products or services offered are not relevant to sex appeal advertisement. Marketers are still seeing sex appeal advertisement as very relevant in promoting products and services thinking sex appeal advertisement technique are the most accepted by consumers and viewers (Zachari, Nawar and Javaherizadeh, 2018). Some of the methods usually used to promote the products are through obscene and vulgar scenes or words.

Sex appeal advertisements method usually use women in the advertisement as women are always seen as a sex object. Women were as well perceive as a weak figure whom prefer attention from men and always are waiting approval from men in daily lifecycle (Shahwar, 2018).

In this review, the discussion will not only discussing the importance of advertisement in improving business but also to highlight the non-acceptance of using women in sex appeal advertisement. 


\section{Literature Review}

Advertisements are accepted well by consumers once it showing the actual picture of the products and in a very attractive manner as it makes it easier for consumers to keep the advertisements in the long term memory (Sallam and Agamnash, 2016). Advertisement does not limit only to notify potential consumers about products and services but it may also assist institutions to advertise public service advertisement as well as medium to promote political candidates manifesto (Shahwar, 2018). Consumers feel close acceptance towards products if it is shown as real, authentic and credible in an advertisement (Sallam and Agamnash, 2016). It is suggested that advertisement serves two basic objectives which are to notify and to convince the potential consumers (Shahwar, 2018). In a research written by Curtis et. al., a FCB Model (Foote, Cone and Belding) is used to assist in strategic planning of an advertisement thus the advertisement watch or read by consumers will not be forgotten easily (Curtis, Arnaud and Waguespack, 2017). Moreover, FCB model created by Vaughn, 1980 consumers ability to remember an advertisement will be determine through information (Learn), attitude (Feel) and behaviour (Do). Effective advertisement shown through receiver's high acceptance towards the advertisement and it able to transform the opinion of receivers to accept the existence of a product (Sallam and Agamnash, 2016).

It is important to understand the ethics of advertisement before judging the ethical sides of advertisements (Munjal, 2016). Consumers evaluate advertisement through criteria through three main beliefs which include idealism, pragmatism and relativism (Munjal, 2016). Idealism focus on mutual understanding on right and wrong principle which is straightforward without any ambiguous region in understanding an advertisement (Munjal, 2016). Meanwhile, relativism are more on cultural acceptance which explain that an advertisement may be accepted in one place but might be rejected in other place (Munjal, 2016). Furthermore, pragmatism are depending on the acceptance of majority of the viewers of the advertisement (Munjal, 2016). Such as in Malaysia, the acceptance of sex appeal is verily on the strength of belief of the society, as some of the Muslim's population are even seeing sex appeal advertisement as a no issue matter (Krisnan and Run, 2016).

Due to increase in products and services development and innovation less attention were given to advertisements shown in the media force marketers to apply manipulation method in ensuring the advertisement of products and services will again grab consumer's attention (Curtis et. al., 2017; Koszembar-Wiklik, 2016). Adding to the statement the manipulation of advertisement also known as controversial advertisement and it may include the elements of provocative images and issues that are not usually discussed openly such as sex, death and violence. Even though advertising is important, unfortunately there are irresponsible companies that take ethical advertising lightly without considering the effects to society. Unethical advertising can be classified into several division and it includes disclosing competitors, promoting prohibited items, promoting products that do not have proper verification such as medicines, women stereotyping and manipulating of children in advertisement (Munjal, 2016). It is stated that there are seven appeals that can be considered when creating advertisements and it includes "fear", "humour", "sex", "music", "rationality", "emotion" and "sarcristy" (Zachari, Nawar and Javaherizadeh, 2018; Clow and Baack, 2007). In this review the unethical advertising is focusing on women stereotyping in advertisements specifically on sex appeal advertisement. Sex appeal in advertisement able to be presented in various way either through video and printed media (Zachari et. al., 2018). In sex appeal advertisements, gender stereotyping were used to promote products (Khanfar, 2018). 
Women are seen as a beautiful and sexy figure thus focusing on women appearance are important and it is compulsory to be highlighted in every advertisement that is focusing in using sex appeal in the advertisement (Shahwar, 2018). In an advertisement women is used to show physical appearance and to be the base opinion of beauty standard (Das and Sharma, 2016). In usual scope, women's beauty are used to promote cosmetics by highlighting crucial parts of women's body to promote sexiness and beauty towards women consumers in general (Shahwar, 2018). Other than stereotyping women as definition of beauty, women were as well stereotyped as weaker than male whom were seen as more dominant creature and believe to be able to handle women's personality (Hust, Rodgers, Cameron and Li, 2019). Moreover, women were stereotyped to be a stay at home and uneducated personality whom lacking in terms of knowledge than men (Shahwar, 2018).

Sex appeal advertisement is really giving good contribution in enhancing the memories of viewers but it is also believe it did not give the extra attention needed for the products appeared in the advertisement (Kumar, 2017). Marketers believe that sexual appeal advertisement is a sturdy tools in ensuring the effectiveness of delivery of advertisement (Longani, 2019). Women are the most portrayed in and advertisement to show the meaning of beauty to consumers (Das and Sharma, 2016). There are companies that accomplish their mission to be well known just by using almost naked advertisements. The most well-known companies whom excel in using sex appeal advertisements are Abercrombie and Fitch, Carl's Junior and Budweiser (Newbold, 2017). Moreover, it is also used by car company, Nissan whereby the printed advertisement are showing a pink car with a woman wearing pink lingerie together in one space and it is enhance with "electric toy" wordings which create a perception that women is objectified as an "electric toy" (Kumar, 2017). Three ways brands are using sex appeal advertising in their brand is through three methods. It will be teasing, supporting, using the nature of the product and subliminal advertisement. These methods are proven as useful in attracting the customers to remember the advertisement and giving a chance to check on the products offered by the particular side. Furthermore, sex appeal in advertisement are able to attract necessary attention, encourage stimulation and able to stay in long term memory of the viewers (Longani, 2019). Sex appeal advertisement is a hype to men more than women (Samson, 2016). Consumer acceptance then is used to determine either the advertising method is good for the products. It is accepted by certain population that sexy were mostly determine (66\%) based on physical characteristics and the least is the level of space consideration of models (15\%), (Longani, 2019).

Even though women were used in the advertisement widely but the acceptance of the women as a sex appeal were not highly accepted by all. In a research done by Zachari et. al., 2018 it is stated that new generation are not looking forward with advertisements that showing only physical appearance of the models without including any other important information about the services or products offered (Zachari, et. al, 2018). Moreover, the acceptance of sex appeal in advertisement will be relevant if women were used in an advertisement while promoting items that is highly related to women such as promoting body oil (Zachari et. al., 2018). Advertisement that is using sex appeal without showing relevance between product and services offered will be a turn off for viewers to accept the content of the advertisement. Added that age difference also affects how the advertisement is accepted. Added in the research, with supporting facts from Kilbourne (1990), men disrespect women when women are portrayed negatively in an advertisement. In comparison men see women as a more respectable figure when women are given professional roles in an advertisement. Furthermore, sex appeal in advertisements are not entirely accepted by all 
culture in the globe and the acceptance of products and services are highly depending on the local culture and not based on advertisement. It is also supported by Erkaya in a research based on Turkish adolescents, 2018 whereby stating that sex appeal advertisements are only appropriate if it is directly related to the products offered and not randomly used to enhance the look of the advertisement (Erkaya, 2018). Moreover, in the research stated by Erkaya the acceptance of using women as a sex appeal representative in an advertisements were not accepted well by women. It was explained further in the research that sex appeal advertisements may not be the strongest reason that makes the products and services consume by the target market as the acceptance of products and services do not depends extremely on the advertisements alone. Another research titled Advertising Effect on Consumer Emotions, Judgements, and Purchase Intent shared that the outcomes of unethical advertising are not as sweet as expected by marketers (Curtis et. al., 2017). In the research focusing on controversial advertising which is also part of unethical advertising stated that this kind of advertising strategies are not suitable for all as it may bring undesirable reaction such as shame, loath, gross out, anger and annoyance and at the same time causes consumers to decide on not to purchase the products and services offered. In addition, consumers are seen as more attracted to purchase products and services that is using proper language. Stated in the study as well, younger consumers are prone to purchase products and services if it is the advertisement are making the balance relation between the advertisements and the products and services offered. Additional note from the research, younger generation are actually aware about unethical advertising and able to feel if the advertisements shown contain contents related to sexual appeal or any other provocative elements. It is stated in the research as well airline industry have no exception in including sex appeal elements in the advertisements. Fortunately, after the establishment of The Stewardesses for Women's Rights (SFWR) in 1972 more and more airline advertising are now moving forward to show great improvement from making women as a sex symbolism in an advertisement it shift to create more focus on air travel safety and comfort while flying in the advertisement.

Sex appeal advertisement were also opposed and not well accepted by most women (Ali, 2018). In Ali's research it stated that women are not happy when most of the time the sexual representation is focusing totally towards women. In the research which is supported by another scholar Malik (2014) in her research "Women's Objectification by Consumer Culture" caused women to feel more at risk as well as feeling of inadequacy towards individual physical appearance. Moreover in Ali's research, it also include that women used as sex appeal in advertising may increase attraction towards the advertisement but will not create enough awareness towards products or services offered by the marketers. Adding to it women in sex appeal advertisement format was portrayed negatively and clouds women positive potentials thus reduce women credibility in the eye of society. Moreover, through the research done by Ali sex appeal advertisement are creating irrelevant beauty standards that may not be achieve by women in real life thus develop the potential of mental health due to inability for women to cope with the unrealistic demands from society and opposite sex. In the research stated as well women used as sex appeal object in advertisement did not have strong autonomy towards themselves, always seeking for approval from the opposite sex, easily replaced and lot more negative character that lead to women is vulnerable, needed assurance and highly dependence towards men. Added to the statement Alves (2017), stated sex appeal advertisement does increase the development of rape culture due to women are always symbolize as sex object that can be won by opposite sex. Furthermore, unethical advertising is extremely opposed by religions as religions has create an influence towards the growth of 
advertisement in certain region in the globe as religions are creating guidelines to be followed before creating any types of advertisements (Purnama and Safira, 2017). Muslim is one of a religion that never agreed to sex appeal advertisement as it will always comeback negatively towards women. Besides, in the research sex appeal advertisement are perceive as disgusting, insulting and generalizing women. Moreover, in Islamic point of view it is important to ensure that everything is done accordingly following what had been taught in Islam. Therefore, sex appeal advertisement is not one of favourable method to be use in Islamic region in the world. Through the review it is clear that unethical advertising is still happening but it is not well accepted by all. Even though unethical advertising specifically sex appeal advertisement, that is manipulating women were still seen as a powerful tool for marketing activities but it does not mean that sex appeal advertisement are relevant and effective to promote products and services to the consumers. Companies should consider using better marketing tools which will provide more positive influence instead of long lasting negative misleading advertisement. Sex appeal advertisement are not highly accepted by most women as it project negative attributes towards women in general. Moreover, most women will need to live uncomfortably as men whom taken sex appeal advertisement as a projection of all women character will act as if women wanted to be treated lowly as how it is projected in advertisements. This matter will then create more unnecessary issues in the future. Therefore, advertisements provided by marketers should be focusing more on to provide accurate information and creating awareness on the specialty of the products and services offered. Moreover, marketers must be able to evaluate major consumer's acceptance on the types of advertisement provided. In a nutshell it is always important for marketers to create advertisements that reflect the products and services special features and to always made it relevant to the concept of the products and services.

\section{Methodology}

Research methodology for this review paper are documentary analysis as it is a qualitative paper whereby no interview or questionnaire were given to respondents. All input are derived from other researcher's previous work without the researcher's involvement (Bowen, 2009). Articles are mainly focus from the year 2016 until 2020. The articles are mainly derived from reliable publications such as Journal of Health Communication, Journal of International Women's study, Asian Journal of Business Research, International Journal of Advanced Scientific Technologies in Engineering and Management Sciences, Institute of Innovation in Technology and Management, International Journals of Economics, Commerce and Management and the list continue.

The researcher's work used are mainly focusing on advertisements and usage of women in sexual appeal in advertisement. Research taken if it is related in explaining advertisements and the criteria that creates ethical and unethical advertisement. On the other hand, papers that are strongly supporting sex appeal advertisements will be omit and will not be considered to be use in this review paper. 


\section{Results and Discussion}

The results from researches that did not entirely support sexual appeal in advertising are describe as followed:

\begin{tabular}{|c|c|}
\hline The research & Description of the data results \\
\hline $\begin{array}{l}\text { Purnama dan Safira, 2018; } \\
\text { Investigating Islamic Advertising } \\
\text { Ethics: Perceptions of } \\
\text { Indonesian Muslims }\end{array}$ & $\begin{array}{l}\text { Based on the result of this research Indonesia Muslim } \\
\text { put honesty as the most important criteria to be include } \\
\text { in an advertisement. Moreover, in the result stated that } \\
\text { women put great importance in using ethical } \\
\text { advertising in advertisement. }\end{array}$ \\
\hline $\begin{array}{l}\text { Sana Ali, 2018; Women } \\
\text { Objectification and Advertising: } \\
\text { An Analysis of Sexually } \\
\text { Objectified Portrayal of Women } \\
\text { in Television Advertising in } \\
\text { Pakistan }\end{array}$ & $\begin{array}{l}\text { Through the research of Ali, sex appeal advertisement } \\
\text { shows minimal significant between using sex appeal in } \\
\text { advertisement with the acceptance and purchase of the } \\
\text { products shown. Research was done by observing the } \\
\text { amount of advertisement that are using women as the } \\
\text { main subjects on several different main TV channel in } \\
\text { Pakistan. One strong reason that support the non- } \\
\text { acceptance of using women or any arousing technique } \\
\text { in advertisement are highly because Pakistan is a } \\
\text { country populated with majority Muslim. The Chi- } \\
\text { square value are showing } 0.747 \text { and P value below or } \\
\text { equal to } 0.05 \text { indicates that sex appeal advertisement } \\
\text { does not work effectively in Pakistan region. }\end{array}$ \\
\hline $\begin{array}{l}\text { Erkaya, 2018; How Do Turkish } \\
\text { Adolescents React To Sexual } \\
\text { Appeals in Advertising? A Field } \\
\text { Experiment }\end{array}$ & $\begin{array}{l}\text { Erkaya focus on Turkish market whereby majority of the } \\
\text { citizens are Muslim. Stated in his finding, it is important } \\
\text { for advertising companies or marketers of products and } \\
\text { services to be extremely cautious because the } \\
\text { acceptance of using women and sexual appeal in } \\
\text { advertisement will not be accepted well in the region. It } \\
\text { is important for all marketers and advertisers to } \\
\text { understand the sensitivity before proceeds in airing any } \\
\text { unethical advertisement especially if it is related to } \\
\text { women and sex appeal. }\end{array}$ \\
\hline $\begin{array}{l}\text { Curtis, Arnaud and Waguespack, } \\
\text { 2017, Advertising Effect on } \\
\text { Consumer Emotions, } \\
\text { Judgements and Purchase } \\
\text { Intent }\end{array}$ & $\begin{array}{l}\text { In Curtis et. al., } 2017 \text { research the findings are stating } \\
\text { that acceptance of sex appeal performance are varied. } \\
\text { As this research is done in more open minded society it } \\
\text { is seen that the acceptance towards sex appeal } \\
\text { advertisement varied from individuals to another } \\
\text { individuals. Even though the acceptance of sex appeal } \\
\text { advertisement varied from one individual to another } \\
\text { high frequency sex appeal advertisement are not giving } \\
\text { any positive influence other than creating moment of } \\
\text { disgust especially from female viewers. Thus, sex appeal } \\
\text { advertisement still seen as unacceptable. }\end{array}$ \\
\hline $\begin{array}{l}\text { Zacha } \\
\text { Javah }\end{array}$ & $\begin{array}{l}\text { In this research even though through the data sex } \\
\text { appeal advertisement are showing positive influence }\end{array}$ \\
\hline
\end{tabular}


Impact of Sexuality in

Advertisements on Consumers

Purchase behaviour: A Social

Media Perspective towards the purchase of products and services but it is not giving good influence to women as public are projecting negative image towards women in general. As shown in the data collected from the research $58 \%$ from the respondents are feeling offended with advertisement that includes sexual appeal.

\section{References}

Ali, S. (2018). Women Objectification and Advertising: An Analysis of Sexually Objectified Portrayal of Women in Television Advertising in Pakistan. Global Media Journal, 16(31), 1-6.

Curtis, T., Arnaud, A., and Waguespack, B. P. (2017). Advertising Effect on Consumer Emotions, Judgements and Purchase Intent. Asian Journal of Business Research, 7(2), 57-73.

Das, M., \& Sharma, S. (2016). Fetishizing Women: Advertising in Indian Television and Its Effects on Target Audiences. Journal of International Women's Studies, 18(1), 114132.

Erkaya, Y. (2018). How Do Turkish Adolescents React To Sexual Appeals in Advertising? A Field Experiment. Global Media Journal Scientific Quarterly of the Vistula University, 3(57), 100-109.

Hu, F., Wu, Q., Li, Y., Xu, W., Zhao, L., \& Sun, Q.,(2020). Love at First Glance but Not After Deep Consideration: The Impact of Sexually Appealing Advertising on Product Preference. Frontiers in Neuroscience, 14(145), 1-10.

Hust, S. J. T., Rodgers, K. B., Cameron, N., \& Li, J. (2019). Viewers' Perceptions of Objectified Images of Women in Alcohol Advertisements and Their Intentions to Intervene in Alcohol-Facilitated Sexual Assault Situations. Journal of Health Communication, 24(3), 328-338.

Huq, S. M., Nekmahmud, M., \& Aktar, M. S. (2016). Unethical Practices of Advertising in Bangladesh: A Case Study on Some Selective Products. International Journals of Economics, Finance and Management Sciences, 4(1), 2326-9561.

Khanfar, A. M. (2017). Advertisement and Gender: A Critical Discourse Analysis. مجلت آداب 27- 58.

Krisnan, U. D., \& Run, E. C. (2016). Malaysian Malay's Perspective on Printed Sexy Advertisement. International Journal of Business and Management, 11(8), 145-151.

Kumar, S. (2017). Representation of Women in Advertisements. International Journal of Advanced Scientific Technologies in Engineering and Management Sciences, 3(1), 2528.

Dang-Longani, K. (2019) Does Sexual Appeal in Advertisement Really Attract Viewers and Affect Consumer Buying Decision? With Special Reference to Rural Area in India, $9^{\text {th }}$ $10^{\text {th }}$ January 2019, International Conference on Media Ethics 2019.

Munjal, N. (2016). A Study on Ethical Issues in Advertising and Analyzing Different Unethical Advertisements with Results of ASCI Decisions: An Indian Perspective. Institute of Innovation in Technology and Management, 5(2), 238- 242.

Purnama, F., \& Safira, A. (2017). Investigating Islamic Advertising Ethics: Perceptions of Indonesian Muslims. Journal of Emerging Economies and Islamic Research, 5(2), 4357. 
Sallam, M. A., \& Algamnash, F. A. (2016). The Effect of Attitude towards Advertisements on Attitude Brand and Purchase Intention. International Journals of Economics, Commerce and Management, 4(2), 509-520.

Syafiq, A., Haque, A., \& Abdullah, K. (2016). A Collection of Islamic Advertising Principles. International Journal of Islamic Marketing and Branding, 3(3), 572-592.

Zachari, A., Nawar, Y. S., \& Javaherizadeh, E. (2018). The Impact of Sexuality in Advertisements on Consumers Purchase behaviour: A Social Media Perspective. $8^{\text {th }}$ International Conference on Reconstructing of the Global Economy, University of Oxford, UK, 9-10 July, The Business and Management Review. 